\title{
The Use of Information and Communication Technology (ICT) in the Implementation of Instructional Supervision and Its Effect on Teachers' Instructional Process Quality
}

\author{
Bambang Budi Wiyono ${ }^{1, *}$, Agus Wedi $^{2}$, Saida Ulfa ${ }^{2}$ and Arda Purnama Putra ${ }^{3}$ \\ 1 Educational Administration Department, Faculty of Education, Universitas Negeri Malang, \\ Malang 65145, Indonesia \\ 2 Educational Technology Department, Faculty of Education, Universitas Negeri Malang, \\ Malang 65145, Indonesia; agus.wedi.fip@um.ac.id (A.W.); saida.ulfa.fip@um.ac.id (S.U.) \\ 3 Early Childhood and Elementary School Teacher Education Department, Faculty of Education, Universitas \\ Negeri Malang, Malang 65145, Indonesia; arda.purnama.fip@um.ac.id \\ * Correspondence: bambang.budi.fip@um.ac.id
}

Citation: Wiyono, B.B.; Wedi, A.; Ulfa, S.; Putra, A.P. The Use of Information and Communication Technology (ICT) in the Implementation of Instructional Supervision and Its Effect on Teachers' Instructional Process Quality. Information 2021, 12, 475. https://doi.org/10.3390/info12110475

Academic Editors: Chih-Peng Fan, Konstantinos E. Psannis,

Muh-Tian Shiue and Hsi-Pin Ma

Received: 11 October 2021

Accepted: 15 November 2021

Published: 16 November 2021

Publisher's Note: MDPI stays neutral with regard to jurisdictional claims in published maps and institutional affiliations.

Copyright: (c) 2021 by the authors. Licensee MDPI, Basel, Switzerland. This article is an open access article distributed under the terms and conditions of the Creative Commons Attribution (CC BY) license (https:// creativecommons.org/licenses/by/ $4.0 /)$.

\begin{abstract}
This study aimed to explore communication techniques based on the information and communication technology (ICT) used in the implementation of instructional supervision to determine their effect on the teacher's learning process and find effective techniques to improve the quality of the teacher's learning process. This research was conducted in Blitar City with a sample of 60 teachers through a random sampling technique. The data collection technique used a rating scale, checklist, and open-form questionnaire. Descriptive statistics were used to describe the data, while the Pearson product-moment correlation techniques and multiple regression were used to test the research hypotheses. The results show that the most widely used ICT-based communication techniques are WhatsApp, Google Meet, Zoom, Skype, and Google Forms. These are followed by email, video-recording, and audio-recording techniques. The use of ICT is still rare. There is a significant relationship between the use of ICT in instructional supervision and the quality of the teacher's teaching-learning process, except when using telephones and televisions. ICT techniques are most commonly used for synchronous communication, followed by use for sharing information, and recording activities. The use of ICT in instructional supervision simultaneously affects the teacher's instructional process.
\end{abstract}

Keywords: information and communication technology; synchronous; sharing information; recording tools; instructional supervision; teaching-learning process

\section{Introduction}

Improving the quality of education has become a priority for national development, in addition to equity, expansion of access, and relevance. This is because the quality of education in Indonesia is still relatively low. The results of the 2018 PISA show that Indonesia is still ranked 75th out of 80 countries [1]. When viewed globally, the quality of education in Indonesia is also still below that of neighboring countries, namely, Singapore, Malaysia, Thailand, and Vietnam. Therefore, the government is striving to improve the quality of the existing education.

The increase in the quality of education is indicated by the increase in student learning outcomes. The first step to improve the quality of education is improving process and student learning outcomes. One of the main learning system components that determines student learning outcomes is the teacher. Some research results show that the quality of teacher learning is very decisive for student learning outcomes (Bicer, 2014; Vizeshfar and Torabizadeh, 2018) [2,3]. Therefore, to improve student learning outcomes, the quality of teacher learning needs to be continuously improved. 
The government has implemented many policies to improve teachers' abilities at the central, provincial, and city or district levels. One of the policies that was launched and promoted by the government involves the supervision of teacher learning. Policies to increase teacher competence have been enacted in several other Asian countries $[4,5]$. However, few of these programs have been proven to be effective in improving the quality of teaching. Some research results indicate that instructional supervision activities are not effective in improving the quality of teacher learning [6-8].

On the other hand, the development of information and communication technology brings changes to the process of implementing instructional supervision. Since the beginning of the COVID-19 pandemic, face-to-face supervision activities have not been feasible. Many supervision activities are carried out by utilizing information and communication technology. However, the extent to which these instructional supervision activities use communication and information technology is still in question. Its effect on improving the quality of teaching is still not certain. Therefore, it is necessary to carry out further research.

\subsection{Instructional Supervision}

Instructional supervision is the process of assisting teachers in improving and enhancing the learning process. Such assistance can come in the form of guidance, coaching, encouragement, stimulation, or other activities. The implementation process can be viewed from the perspectives of approach, technique, and principles of instructional supervision.

This approach is a behavioral orientation, applied by the supervisor in the process of implementing supervision. This can be carried out using directive supervision, nondirective supervision, or a collaborative supervision approach [9]. Directive supervision places more emphasis on supervisors, and supervisees tend to follow what the supervisor says. Its psychological foundation lies in behavioral psychology. In contrast, the nondirective supervision approach places more emphasis on supervisees, and supervisors tend to listen and provide encouragement. The psychological foundation of this approach is humanistic psychology, wherein, during the learning process, the individuals themselves are actively identifying and solving problems. Meanwhile, collaborative supervision is a combination of the two approaches. Supervisors and supervisees are both active and share responsibilities. Its psychological foundation lies in cognitive psychology.

The techniques are the methods used to carry out the supervision. The supervisees can be grouped into two, namely, those using group techniques and those using individual techniques. Group techniques are carried out when there is a high number of supervised teachers. Teacher meetings, teaching demonstrations, workshops, training, upgrading, and discussions are examples of group techniques. Individual techniques are carried out if only one teacher is being supervised. Class visits, self-assessments, class observations, and individual meetings are examples of individual techniques. Judging from the implementation process, supervision techniques can also be classified into two, namely, direct techniques and indirect techniques. Direct techniques are implemented when the supervisor and supervisee communicate directly. Workshops, class visits, and teacher meetings are examples of direct techniques. Indirect techniques are implemented when communication between supervisor and supervisee is carried out through media. Supervision bulletins are examples of indirect techniques.

From another perspective, instructional supervision can also be categorized as intensive development, cooperative development, or self-directed development [10]. Intensive development is a form of development that refers to clinical supervision, where supervisors intensively provide guidance to supervisees; cooperative development refers to collegial supervision; self-directed development refers to the supervision of independent development.

\subsection{ICT-Based Instructional Supervision and Teacher's Instruction}

The purpose of instructional supervision is to improve the teachers' ability to carry out teaching tasks. The teacher's teaching process is a system. It contains interrelated 
components, namely, objectives, materials, strategies, models, methods, tools, and evaluations [11]. The quality of the teacher's teaching process can be viewed from these perspectives. Teaching objectives should be clearly formulated, supported by good content, and equipped with the relevant materials and tools. A good teaching process should utilize effective models and methods and complete the appropriate evaluations. Instructional supervision is carried out to improve the quality of the teacher's teaching process and achieve optimal teaching results.

Several studies have shown significant results. Teacher participation in teacher working group activities, as one of the collegial supervision techniques, affects teacher professionalism [12]. Self-evaluation is an independent supervision technique that can also significantly improve a principal's transformational leadership [13]. Training, as an intensive development, has a significant effect on teacher productivity [14]. In addition, self-reflection, as a form of independent supervision, can also increase teacher professionalism [15].

On the other hand, other studies have led to insignificant results. In-service education as a supervision technique does not affect teacher performance [16]. This shows that instructional supervision has not been fully effective at improving the overall competence of teachers. Although supervision is continuous, the teacher's ability to carry out tasks, especially teaching tasks, is often still suboptimal [17]. The principal as a supervisor in managing learning has also not shown maximum quality [18]. Humanistic collaborative supervision influences teacher competence but has not been associated with technological developments [19]. Therefore, it is necessary to conduct more in-depth research related to the effectiveness of these instructional supervision techniques, related to the use of ICT, to find effective instructional supervision techniques in line with today's ICT developments.

In line with the development of communication and information technology, the implementation of instructional supervision cannot be separated from the use of these technologies. These communication techniques can be in the form of communication media to share long-form writing or blogging, such as WordPress, Tumblr, or Blogger; short-form writing, such as texting, Facebook, Twitter, Google Plus; or images such as Snapchat, Pinterest, and Instagram. Supervision media is also a synchronous communication tool, with examples including Skype, Google Hangouts, and Second Life. Social networking platforms have been developed for teachers, researchers, and professionals, such as LinkedIn, ResearchGate, Academia.edu, and Vitae [20]. These communication techniques can be applied to the process of implementing learning supervision. However, the extent to which ICT-based communication techniques help with the implementation of learning supervision is still unknown. How much of an effect ICT can have on improving the quality of teaching is still an open question. Some research results related to the use of ICT in learning have not shown optimal results [21,22]. The use of ICT in learning has also not shown a significant effect on student learning outcomes [23,24]. Likewise, in school management, ICT has often not been used optimally $[25,26]$. The use of ICT to conduct school administrative tasks or establishing school-community relations is still poor. It is also not known how much of an influence the use of ICT in school management has on school performance.

Several studies have been conducted on the use of ICT in the implementation of instructional supervision, but the results have been mixed. Its influence on the teacher's learning process has also not been studied in depth. The communication techniques used also vary, but the effectiveness of each technique has not been studied. One study showed that the use of web-based tools in supervision can increase collaboration between supervisors and supervisees [27]. The use of videoconferencing, email, and teleconferencing, if carried out in accordance with appropriate procedures, can be effective techniques for developing employee professional competencies, but this has not been empirically proven in the field [28]. Another study using tablets as a digital tool showed that they can improve focus, strengthen motivation, increase feedback, increase opinion-sharing, improve coherence, improve structure, and improve preparation and reflection in the implementation of 
supervision, but its effect on the teacher teaching-learning process has not been studied [29]. Several studies on the use of virtual supervision for student guidance have shown effective results, but the effectiveness of communication techniques has not been studied [30-32]. The use of video conferencing in student supervision is felt to be more effective, but its effect on the learning process has not been proven [33]. Self-efficacy and teacher performance did not show significant differences between electronic-based supervision and traditional supervision [34]. Based on some of the results of this study, it is necessary to further study how the use of ICT in instructional supervision influences teachers' instructional processes.

\subsection{Research Purposes}

The research was carried out based on a description of the background. This study aims to (1) describe the intensity of the use of ICT in the process of implementing instructional supervision, (2) describe the effectiveness of the use of ICT in the implementation of instructional supervision, (3) measure the effect of the use of ICT in instructional supervision on the quality of the teacher's learning process. The research hypothesis is that the use of ICT in learning either simultaneously or partially affects the quality of teachers' learning.

\section{Materials and Methods}

\subsection{Research Design}

To answer this research question, an explanatory research design is used, namely, describing data, testing correlations and regression, and explaining direct and indirect effects between variables [35]. The research begins with a problem, examines the problem in terms of the results of initial field experience, examines the theory and results of previous research, designs research parameters, develops instruments, collects data in the field, and processes and interprets the research data. The initial research was conducted in Blitar City, with a sample of 60 teachers, which were chosen by a random sampling technique.

\subsection{Research Instruments}

To obtain data in this study, questionnaire and documentation techniques were used as data collection techniques. The research instrument was developed based on the construct of the measured variables. The instrument items were developed based on the theory of ICT-based instructional supervision and the teaching-learning theory, as well as the results of observations in the field. The use of ICT in instructional supervision is seen from 25 supervision techniques with 12 communication techniques. The twenty-five techniques are upgrading, training, course, teacher workgroup meeting, seminar, discussion, lesson study, clinical supervision, collegial supervision, meeting, workshop, classroom visitation, teaching demonstration, symposium, supervision bulletin, action research, in-on-in activity, professional library, classroom intervisitation, school intervisitation, teaching simulation, self-evaluation, teacher orientation, individual conferences, and classroom observation.

The communication techniques used are audio recording, video recording, WhatsApp, email, Google Meet, Zoom, telephone, television, Google Forms, Skype, Facebook, and websites. The twelve techniques are classified into three categories, namely, recording tools, synchronous communication, and sharing information applications. Meanwhile, the quality of the teaching consists of five components, namely, teaching planning, the use of learning models and methods, the use of learning media, the use of learning resources, and the evaluation of process and learning outcomes.

To obtain the validity and reliability of the instrument, it was tested in the field and analyzed. The reliability estimation formula used was Cronbach's alpha, while the instrument validity was analyzed by item for the total analysis. The results of the instrument analysis determined that the reliability coefficient of the instructional supervision instruments was 0.954 , the instructional supervision step was 0.955 , the ICT-based communication technique was 0.943 , the instructional supervision effectiveness was 0.952 , and the teacher's instruction quality was 0.854 . The values of the reliability coefficients are above 0.7 ; thus, it can be 
concluded that the research instruments are reliable. The item-total analysis showed varying results, in which each instrument item obtained a coefficient value. The instructional supervision frequency instrument obtained the coefficient of each item, with a minimum value of 0.439 and maximum of 0.829 ; the instructional supervision step had a minimum of 0.410 and a maximum of 0.838 ; the ICT-based communication techniques had a minimum of 0.543 and a maximum 0.794 ; the instructional supervision effectiveness had a minimum 0.430 and maximum 0.826 ; the teacher's instruction quality had a minimum 0.538 and maximum 0.737 . The values of the item-total analysis of the instruments were above 0.3 ; thus, it can be concluded that the instruments meet the requirements of good item validity.

\subsection{Data Analysis}

Following the research objectives and the types of data that were available, the data analysis technique used in this study is descriptive statistics. This was used to describe the data, including both data about the use of ICT in implementing instructional supervision, and the quality of the teacher's teaching-learning process. Pearson product-moment correlation analysis techniques and regression were used to test the hypothesis, namely the effect of ICT-based instructional supervision on the quality of the teacher's teaching process. The first analysis was conducted using the zero-order correlation of Pearson product-moment, which was intended to determine the coefficient of the relationship between the independent variables and the dependent variable as an initial indicator. Then, a regression analysis was performed to determine the simultaneous correlation of all independent variables with the dependent variable through multiple correlation analysis, to determine the partial correlation, and to find the contribution and predictive values of the independent variables and the dependent variable. To test the classical assumption, the Kolmogorov-Smirnov test and heteroscedasticity and linearity tests were used. The calculations were carried out using the Statistical Program for Service Solution.

\section{Results}

\subsection{Use of ICT in the Implementation of Instructional Supervision}

Following the research objectives, the first result presented in this study is a description of the use of ICT in the teaching received by teachers. The frequency of using ICT in instructional supervision obtained an average score of 1.86. The average value was then included in the classification. Four alternative answers were provided to indicate the frequency: always $=4$, often $=3$, rarely $=2$, and never $=1$. The classification is based on the formula for the highest score (4) minus the lowest score (1), divided by the four classifications so that an interval of 0.75 is found. With the interval, a classification score can be assigned from lowest to highest: $1.00-1.75=$ very low, 1.76-2.50 = low, 2.51-3.25 = high, and 3.26-4.00 very high. Thus, the average value, when included in the four categories of value classification, is categorized as low or rarely carried out. The use of ICT in instructional supervision activities is presented in Table 1.

The values in Table 1 show that the frequency of ICT use in the applied instructional supervision techniques is still relatively low. This means that supervisors are still not using ICT in their supervision activities. Teachers rarely participate in ICT-based instructional supervision activities. The use of ICT is often carried out at teacher working group meetings and teacher meetings, others are still in the low and very low categories. Each instructional supervision technique is carried out in four stages, namely, needs assessment, planning, implementation, and evaluation stages. The results are viewed as different stages of instructional supervision activities and presented in Figure 1.

Figure 1 shows that most of the use of ICT is carried out at the implementation stage of instructional supervision activities (43.12\%), followed by planning $(22.31 \%)$, needs assessment $(22.08 \%)$, and evaluation $(21.02 \%)$. This shows that the use of ICT in instructional supervision is only emphasized to support the implementation of supervision. Many supervision techniques use ICT at the implementation stage, and only a few supervision techniques are used for the needs analysis, planning, or evaluation stages. The needs analysis, planning, and evaluation stages are still largely manually performed. The types of 
communication techniques used also vary. From the results of the data analysis, the types of communication techniques that are applied are broadly presented in Figure 2.

Table 1. Frequency of ICT use in instructional supervision activity programs.

\begin{tabular}{cccc}
\hline No. & Instructional Supervision Activities & Mean & Criteria \\
\hline 1 & Upgrading & 2.31 & Low \\
2 & Training & 2.44 & Low \\
3 & Course & 1.63 & Very Low \\
4 & Teacher Work Group Meeting & 2.63 & High \\
5 & Seminar & 2.07 & Low \\
6 & Discussion & 2.10 & Low \\
7 & Lesson Study & 1.73 & Very Low \\
8 & Clinical Supervision & 1.58 & Very Low \\
9 & Collegial Supervision & 1.54 & Very Low \\
10 & Teacher Meeting & 2.36 & High \\
11 & Workshop & 1.63 & Very Low \\
12 & Classroom Visitation & 2.25 & Low \\
13 & Teaching Demonstration & 2.37 & Low \\
14 & Symposium & 1.32 & Very Low \\
15 & Supervision Bulletin & 1.31 & Very Low \\
16 & Action Research & 1.64 & Very Low \\
17 & In On In Activity & 1.90 & Low \\
18 & Professional Library & 1.32 & Very Low \\
19 & Classroom Intervisitation & 1.49 & Very Low \\
20 & School Intervisitation & 1.47 & Very Low \\
21 & Teaching Simulation & 1.83 & Low \\
22 & Self-Evaluation & 1.86 & Low \\
23 & New Teacher Orientation & 1.92 & Low \\
24 & Individual Conference & 2 & Low \\
25 & Teaching Observation & 1.90 & Low \\
\hline
\end{tabular}

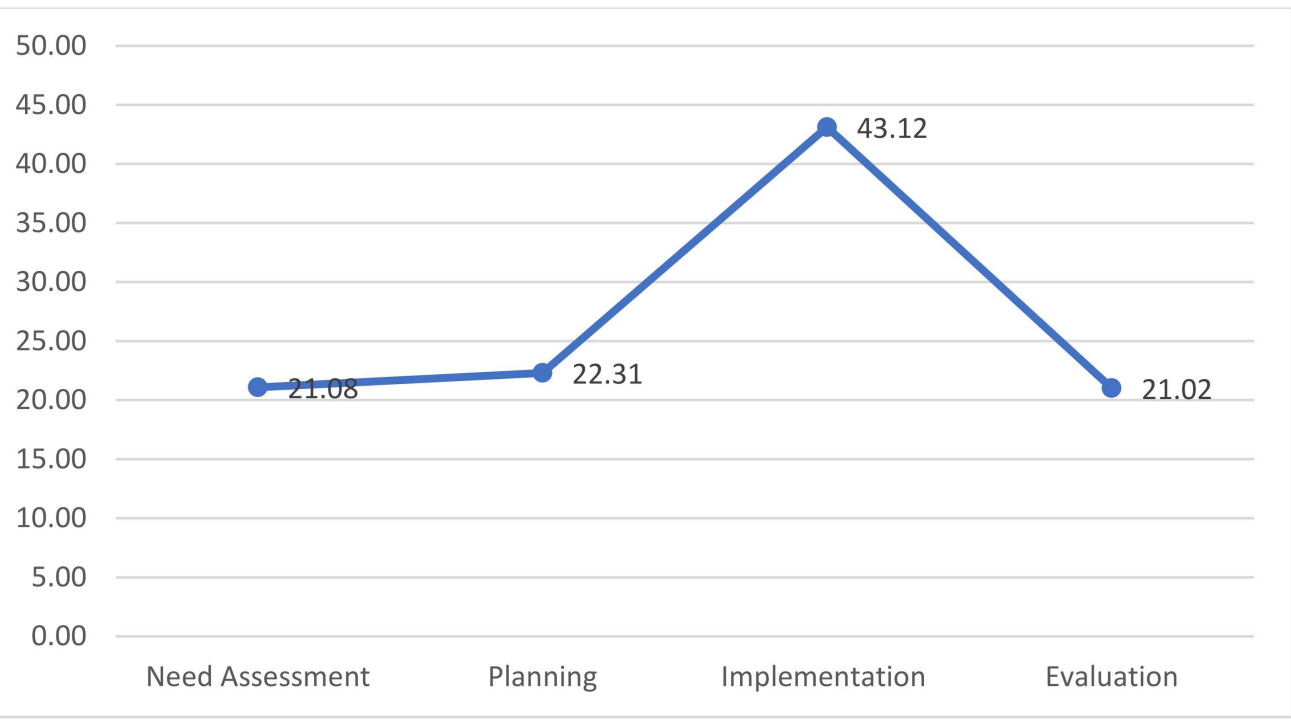

Figure 1. Use of ICT in the stages of instructional supervision activities. 


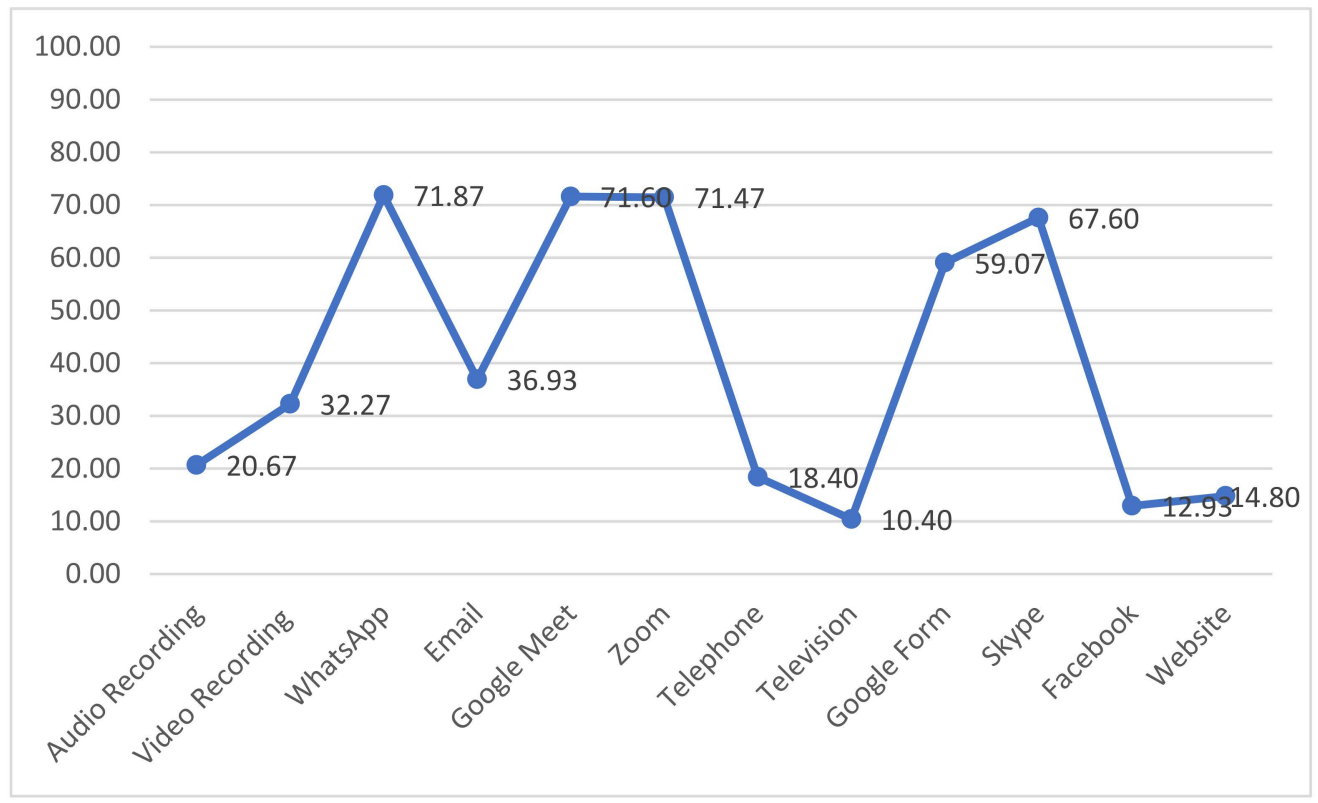

Figure 2. Types of communication techniques applied in instructional supervision activities.

Figure 2 shows that the wifely applied communication techniques are WhatsApp, Google Meet, Zoom, Skype, and Google Forms. These are followed by email, video recording, and audio recording. Rarely used techniques are telephone, website, Facebook, and television. This shows that supervisors more frequently use the communication media that are commonly used in daily communication. In addition, ICT is more widely used to support the implementation of supervision. WhatsApp, Google Meet, Zoom, and Skype are widely used in synchronous interactions, and they are widely used during the supervision process: namely, the interaction between supervisors and teachers. Google Form is widely used to dig up data or collect information.

\subsection{The Effectiveness of ICT-Based Instructional Supervision}

The frequency of ICT use is relatively low; however, in the opinion of the teachers who follow supervision, it is quite effective. The average effectiveness of ICT-based instructional supervision is 2.57. If it were included in the classification of the criteria set, it would be categorized as quite effective. Overall, each supervision technique is presented in Figure 3.

Several effective ICT-based instructional supervision techniques are upgrading, training, teacher workgroup meetings, teacher meetings, teaching demonstrations, seminars, classroom visitation, teacher orientation, one-on-one activity program, discussion, lesson study, individual conferences, and teaching simulation. Meanwhile, courses, workshops, self-evaluation, teaching observations, action research clinical supervision, collegial supervision, classroom intervisitation, school intervisitation, symposia, professional libraries, and supervision bulletins are less effective. These techniques tend to be less used in the implementation of instructional supervision. This shows that ICT, in instructional supervision, is used more in the implementation of frequent supervision techniques. Upgrading activities, training, teacher workgroup meetings, and teacher meetings are the most common supervision techniques. 


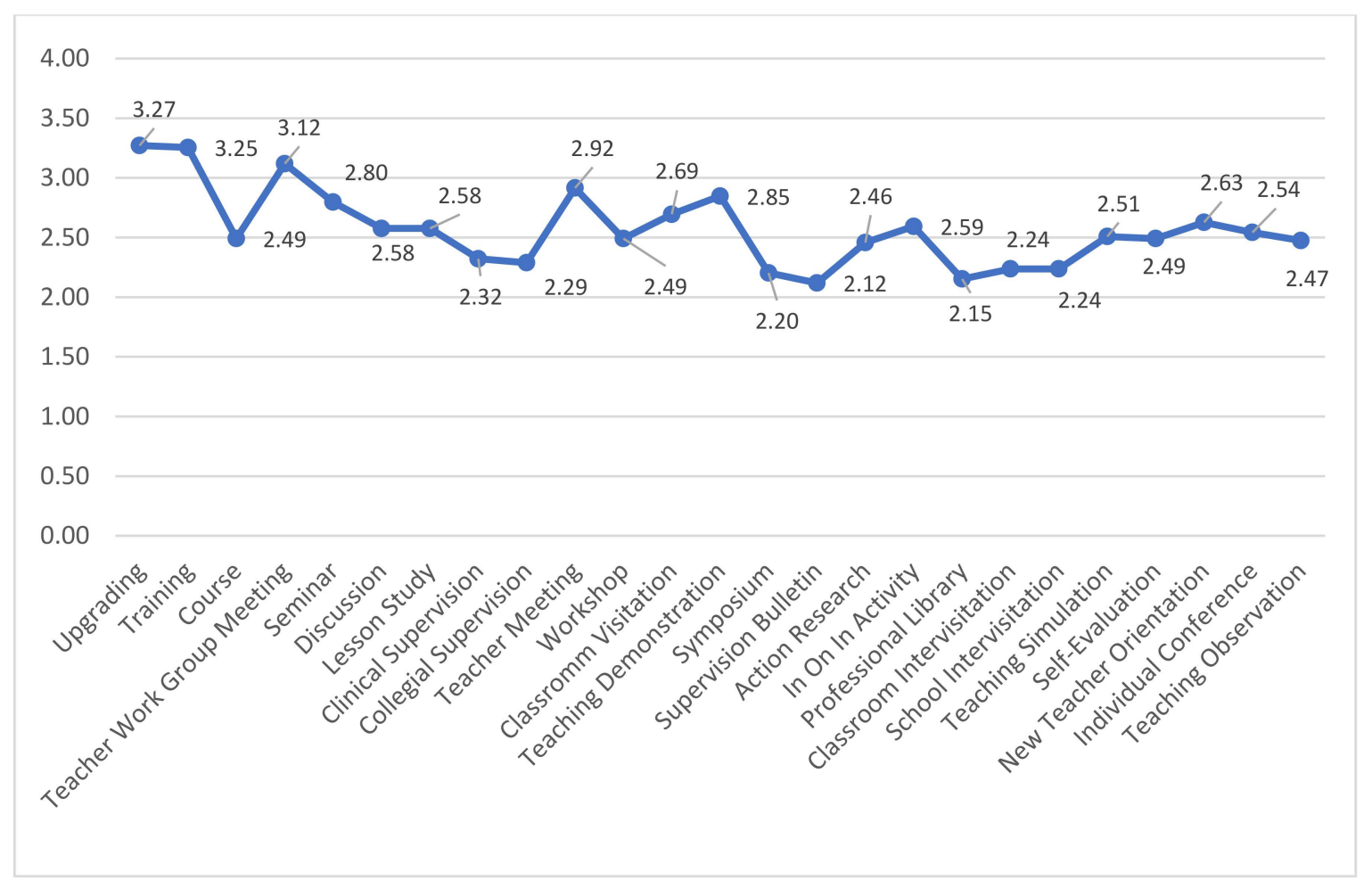

Figure 3. The effectiveness of ICT-based instructional supervision techniques.

\subsection{The Effect of ICT-Based Instructional Supervision on the Teacher's Instruction Quality}

To further see the effectiveness of the use of ICT in instructional supervision, it is necessary to test the hypothesis using inferential statistics through correlation and regression analyses. The first analysis was the Pearson product-moment correlation analysis, which aimed to determine the correlation coefficient of the ICT-based teaching supervision variable with the quality of teacher teaching. The first correlation was the zero-order correlation, a correlation that has not been controlled by other independent variables. The results of the zero-order correlation analysis are broadly presented in Table 2.

Table 2. Results of the zero-order correlation analysis of the effect of the use of ICT on instructional supervision and the quality of the teaching-learning process.

\begin{tabular}{cccccc}
\hline No. & Communication Techniques & $\mathbf{r}$ & $\boldsymbol{p}$ & Criterion & Conclusion \\
\hline 1 & Audio Recording & 0.269 & 0.039 & $<0.05$ & Significant \\
2 & Video Recording & 0.304 & 0.019 & $<0.05$ & Significant \\
3 & WhatsApp & 0.341 & 0.008 & $<0.05$ & Significant \\
4 & Email & 0.326 & 0.012 & $<0.05$ & Significant \\
5 & Google Meet & 0.318 & 0.014 & $<0.05$ & Significant \\
6 & Zoom & 0.316 & 0.015 & $<0.05$ & Significant \\
7 & Telephone & 0.117 & 0.377 & $>0.05$ & Not Significant \\
8 & Television & 0.184 & 0.164 & $>0.05$ & Not Significant \\
9 & Google Form & 0.292 & 0.025 & $<0.05$ & Significant \\
10 & Skype & 0.341 & 0.008 & $<0.05$ & Significant \\
11 & Facebook & 0.202 & 0.125 & $<0.05$ & Significant \\
12 & Website & 0.289 & 0.026 & $<0.05$ & Significant \\
\hline
\end{tabular}

Table 2 shows that, of the twelve ICT-based communication techniques, ten are significantly related to the quality of the teacher's learning process, namely, audio recording, video recording, WhatsApp, email, Google Meet, Zoom, Google Form, Skype, Facebook, and websites. Meanwhile, those that do not have a positive correlation are telephone and television. Thus, in short, it can be said that the use of ICT in the implementation 
of instructional supervision has a positive effect on the quality of the teacher's learning process. The more that ICT is used to carry out instructional supervision, the higher the quality of the teacher's learning process. The higher the use of audio recording, video recording, WhatsApp, email, Google Meet, Zoom, Google Form, Skype, Facebook, and website techniques in the implementation of supervision, the higher the quality of teacher instruction.

These ten communication techniques can be classified into three groups: techniques that are more emphasized for recording tools, namely, audio recording and video recording; techniques for synchronous communication, namely, Google Meet, Zoom, and Skype; and techniques for sharing information, which consist of WhatsApp, email, Google Forms, Facebook, and websites. The general frequency of use is presented in Figure 4.

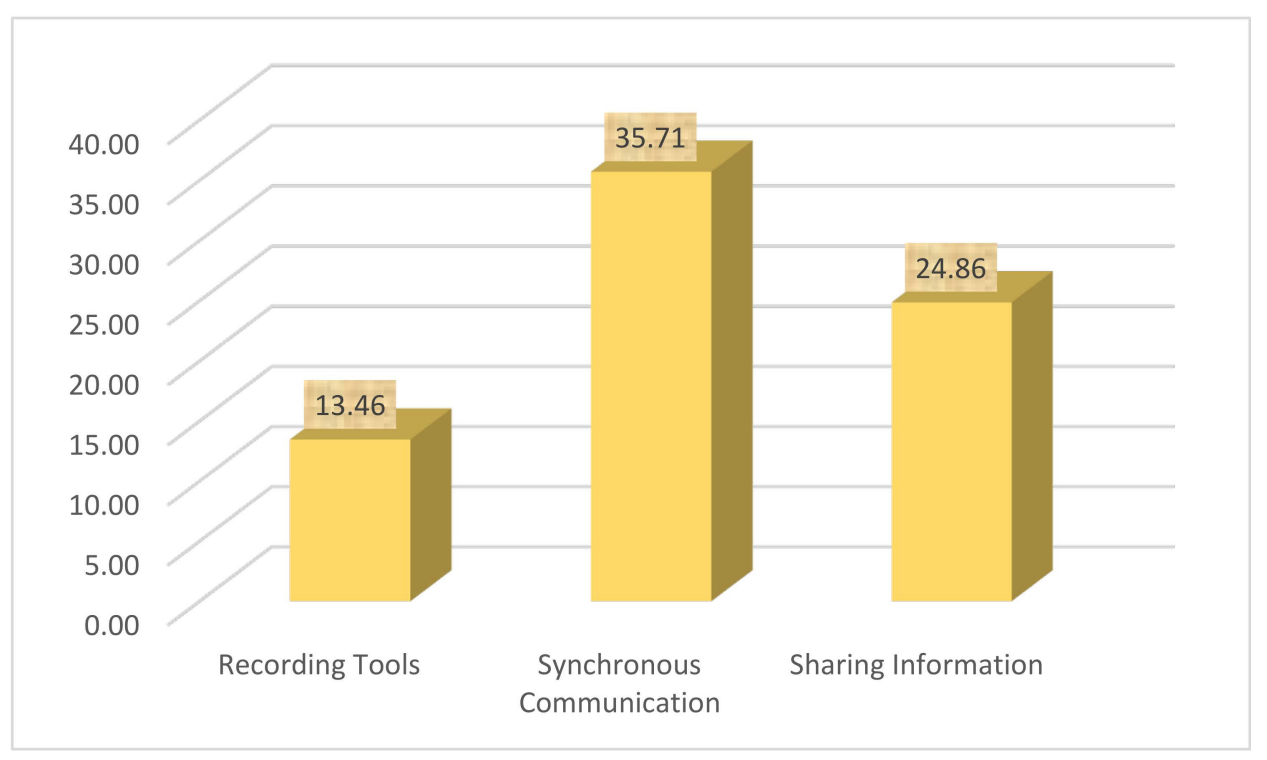

Figure 4. Frequency of use of recording tools, synchronous communications, and sharing information.

Figure 4 shows that the highest use is for synchronous communication, followed by information sharing, and, lastly, as recording tools. Then, this was used to test the influence of the three classification techniques on the quality of teachers' instructions. This effect is not tested by each technique, because several techniques are of a type with the same function, such as Google meet and zoom, which are both synchronous communication media. Audio-recording tools and video-recording tools are similar techniques and have the same function, namely, to record data. Email and Facebook are also similar techniques that have the same function, namely, to send or receive information online. In addition, the purpose of this study is also emphasized: to test the effect of technology-based communication techniques based on their function. Therefore, in the study, the effect of the independent variables on the dependent variable was only tested on the three classifications of the technique. To find the extent of the influence of the three classifications on the quality of teacher's instruction, it is necessary to look at the results of the correlation and regression analyses. Following this research design, the first analysis uses a zero-order correlation analysis: the results are presented in Table 3.

Table 3 shows that there is a significant positive correlation between the three groups of communication techniques and the quality of the teacher's teaching process, which is indicated by the probability error value $<0.05$. The higher the frequency with which each communication technique is used in instructional supervision, the higher the quality of the teacher's teaching. After the zero-order correlation was seen to be significant, a regression analysis was carried out to determine the simultaneous and partial correlation and to determine the contribution and predictive power of the ICT-based instructional 
supervision variable on the quality of the teacher's teaching process. A summary of the results of the simultaneous regression analysis is presented in Table 4.

Table 3. Analysis results of zero-order correlation of variables of recording tools, synchronous communication, and sharing information with the quality of the teacher's teaching process.

\begin{tabular}{cccccc}
\hline No. & Communication Techniques & $\mathbf{r}$ & $\boldsymbol{p}$ & Criterion & Conclusion \\
\hline 1 & Recording Tools & 0.294 & 0.024 & $<0.05$ & Significant \\
2 & Synchronous Communication & 0.325 & 0.012 & $<0.05$ & Significant \\
3 & Sharing Information & 0.356 & 0.006 & $<0.05$ & Significant \\
\hline
\end{tabular}

Table 4. Results of regression analysis of variables of recording tools, synchronous communications, and sharing information on the quality of teacher instruction.

\begin{tabular}{|c|c|c|c|c|c|c|c|c|c|}
\hline \multicolumn{10}{|c|}{ Model Summary } \\
\hline \multirow[b]{2}{*}{ Model } & \multirow[b]{2}{*}{$\mathbf{R}$} & \multirow[b]{2}{*}{ R Square } & \multirow{2}{*}{$\begin{array}{l}\text { Adjusted } \\
\text { R Square }\end{array}$} & \multirow{2}{*}{$\begin{array}{l}\text { Std. Error of } \\
\text { the Estimate }\end{array}$} & \multicolumn{5}{|c|}{ Change Statistics } \\
\hline & & & & & $\begin{array}{l}\text { R Square } \\
\text { Change }\end{array}$ & F Change & df1 & df2 & $\begin{array}{c}\text { Sig. } \\
\text { F Change }\end{array}$ \\
\hline 1 & 0.373 & 0.139 & 0.092 & 10.329 & 0.139 & 2.970 & 3 & 55 & 0.040 \\
\hline \multicolumn{10}{|c|}{ ANOVA } \\
\hline \multicolumn{3}{|c|}{ Model } & \multicolumn{2}{|c|}{ Sum of Squares } & df & $\begin{array}{l}\text { Mean } \\
\text { Square }\end{array}$ & \multicolumn{2}{|c|}{$\mathbf{F}$} & Sig. \\
\hline \multirow{3}{*}{1} & \multicolumn{2}{|c|}{ Regression } & \multicolumn{2}{|c|}{950.644} & 3 & 316.881 & \multicolumn{2}{|c|}{2.970} & 0.040 \\
\hline & \multicolumn{2}{|c|}{ Residual } & \multicolumn{2}{|c|}{5868.237} & 55 & 106.695 & & & \\
\hline & \multicolumn{2}{|c|}{ Total } & \multicolumn{2}{|c|}{6818.881} & 58 & & & & \\
\hline
\end{tabular}

Predictors: (constant), sharing information tools, recording tools, synchronous tools. Dependent variable: instruction process.

Based on Table 4, it can be seen that the influence of the three groups of communication techniques on the quality of teacher's teaching obtained an $\mathrm{R}$ square of 0.139 , F value of 2.970 , and sig. F of 0.010 . The $p$-value is below 0.05 ; thus, it can be concluded that the null hypothesis is rejected and the working hypothesis is accepted: the use of recording tools, synchronous communication, and sharing information application in instructional supervision have a positive influence on the quality of teacher teaching, with a determinant of $13.9 \%$. The partial analysis results are presented in Table 5 .

Table 5. Partial analysis of variables of recording tools, synchronous communication, and sharing information on the quality of teacher instruction.

\begin{tabular}{|c|c|c|c|c|c|c|c|c|}
\hline \multirow[b]{2}{*}{ Variables } & \multicolumn{2}{|c|}{ Unstandardized } & \multirow{2}{*}{$\frac{\text { Standardized }}{\text { Beta }}$} & \multirow[b]{2}{*}{$\mathbf{t}$} & \multirow[b]{2}{*}{ Sig } & \multicolumn{3}{|c|}{ Correlation } \\
\hline & B & Std. Error & & & & $\begin{array}{c}\text { Zero } \\
\text { Order }\end{array}$ & Partial & Part \\
\hline Constant & 33.045 & 2.493 & & 13.256 & 0.000 & & & \\
\hline $\begin{array}{c}\text { Recording } \\
\text { Tools }\end{array}$ & 0.103 & 0.204 & 0.090 & 0.506 & 0.615 & 0.294 & 0.068 & 0.063 \\
\hline $\begin{array}{l}\text { Synchronous } \\
\text { Com. }\end{array}$ & 0.088 & 0.117 & 0.141 & 0.758 & 0.452 & 0.325 & 0.102 & 0.095 \\
\hline $\begin{array}{l}\text { Sharing In- } \\
\text { formation }\end{array}$ & 0.089 & 0.109 & 0.188 & 0.817 & 0.417 & 0.356 & 0.110 & 0.102 \\
\hline
\end{tabular}

Dependent Variable: Instruction Process.

Table 5 indicated that the results of the partial analysis did not have a significant effect. When viewed from the results of the partial analysis, the variable with the highest coefficient of $\mathrm{r}$ is sharing information tools, followed by synchronous communication tools, and then recording tools. Therefore, it can be concluded that the use of ICT in the 
implementation of supervision cannot only partially stand. All three types of use are indispensable in the implementation of instructional supervision.

\section{Discussions}

The findings of this study indicate that the frequency of using ICT in instructional supervision activities is low. The results of this research related to school management also show that school principals still use online communication techniques relatively rarely compared to offline communication in managing schools, especially when managing schoolcommunity relations [25]. School administrative staff also do not use online communication techniques to carry out school administrative tasks [26]. Likewise, the teachers seldom use online communication techniques in the learning process [24]. Thus, the findings of this study corroborate the results of previous studies.

Of the several communication techniques used, the research findings show that the most widely used communication techniques are synchronous, namely, Google Meet, Zoom, and Skype. The results of previous studies also show that lecturers and students use the Zoom or Google Meet applications a lot during the learning process [36]. Thus, the results of this study are in line with the findings of previous studies, where Zoom and Google Meet communication media are widely used in the learning and teaching process. During its development, this research also found that Skype was applied in the implementation of learning supervision. This is because students, teachers, or lecturers tend to be classical, while instructional supervision is naturally a group process, and some are individual. Therefore, the Skype application is commonly used for individual communication.

The results also show that instructional supervision also uses communication techniques that aim to share information, such as WhatsApp, email, Google Forms, Facebook, or websites. Of these techniques, the most widely used are WhatsApp and email. The findings of this study are also in line with the findings of previous studies, which found that these techniques are the most widely used [23]. In this study, we found that Google Forms is also widely used. This is because it is related to the activities that are carried out in instructional supervision, not only sharing information but also finding a lot of information, especially to obtain data at the needs analysis stage. The most effective datacollecting technique uses Google forms. Therefore, these techniques are widely used in the implementation of instructional supervision.

Judging from its effect on the quality of the teacher's instruction process, the findings of this study indicate that the use of ICT-based communication techniques has a significant positive correlation with the quality of the teacher's teaching-learning process. The higher the use of ICT-based communication techniques, the higher the quality of the teacher's learning process. Several studies related to instructional supervision had the same findings. There is a significant positive relationship between several supervision techniques and teacher performance [6]. The frequency of collegial supervision techniques using a collaborative approach affects the performance-based learning that is applied by teachers [37]. The implementation of clinical supervision can also improve teachers' teaching performance [38]. The implementation of the approaches, techniques, and principles of instructional supervision also affect the variety of models and learning materials that are applied by teachers [5]. The more intensively the teacher participates in ICT-based instructional supervision, the higher the teacher's understanding of technological, pedagogical content knowledge. The more the teacher masters technological, pedagogical content knowledge, the higher the use of ICT in the teaching and learning process [39]. The higher the frequency of teachers following the supervision approach and instructional supervision techniques with effective supervision principles, the higher the quality of teacher instruction [27].

When examined more deeply, it can be concluded that the use of ICT in the implementation of learning supervision can increase the effectiveness of instructional supervision. By using ICT in the instructional supervision process, a more effective instructional supervision process can be achieved, leading to an improved teacher teaching performance. 
The findings of previous studies also show the supervision of a diagnostic feedback model that uses ICT in the supervision process, starting from needs analysis, planning, and implementation, and moving to evaluation and follow-up, has proven to be effective [40,41] The results of the research by Mettiäinen and Karjalainen (2011) also show that ICT is very effectively used to supervise students [42]. The results of the research by Rugaiyah et al. (2019) show that clinical supervision using ICT is very effective in improving the teaching quality of teachers [43]. These ICT-based communication techniques can be classified as a form of media for sharing information, media for synchronous communication, or recording devices [20]. The more information is shared, the higher the learning outcomes are achieved [44,45]. In addition, participation in synchronous learning affects the learning performance and outcome $[46,47]$. Thus, the results of this study strengthen and develop the results of previous studies. The low coefficient for relationship or influence is suspected to be because the intensity of supervision is still relatively low, and does not appear to influence the teacher's teaching performance. Therefore, the findings of this study corroborate the results of previous studies. To obtain a generalization, it is necessary to conduct further research using a comprehensive approach.

\section{Conclusions}

The implementation of instructional supervision aims to improve the quality of teachers' teaching processes and outcomes. Several research results have shown that instructional supervision has a positive effect on teachers' teaching performance. However, several other studies have shown different results. Only a few supervision techniques have a positive effect on teachers' teaching performance. The findings of this study corroborate the results of previous studies, which show that the frequency of instructional supervision has a positive effect on the quality of the teacher's teaching-learning process. The more intensively the teacher participates in instructional supervision, the higher the quality of the teacher's instruction.

Several previous studies have not examined the use of ICT when implementing supervision. This research is more emphasized to examine the use of ICT in the implementation of instructional supervision. This is the novelty of this research. The results showed that the use of ICT in the implementation of instructional supervision, followed by teachers, was still low. Most of the communication techniques applied in the process of implementing instructional supervision are quite effective. The results of the analysis of the influence of ICT-based instructional supervision on the quality of the teacher's teaching-learning process also showed significant results, although the coefficient value is still relatively low. This is presumably because the frequency of ICT use is still low. Therefore, the influence is not obvious. However, the results of this study generally indicate that the use of ICT in the process of implementing instructional supervision has a significant effect on the quality of the teacher's teaching-learning process. The higher the use of ICT in the process of implementing instructional supervision, the higher the quality of the teacher's instructional process.

In the stages of instructional supervision, ICT is most frequently used in the stages of needs analysis, planning, and evaluation, and its use is still relatively low. However, the used communication techniques are mainly used for synchronous communication and information sharing, so this is still not evenly distributed. Therefore, the level of effectiveness is still not optimal. It is recommended that this is improved. Supervisors need to increase the use of ICT in the process of implementing instructional supervision, so that it can be more effective in improving the quality of teacher learning processes and outcomes.

The findings of this study are not definite. To obtain more meaningful results, further research is needed, examining the use of each communication technique and each stage of supervision in more detail. It would be better if a more comprehensive research method were used, with a mixing approach. Thus, more comprehensive findings will be obtained for generalization. 
Author Contributions: Conceptualization, B.B.W.; Data curation, A.W., and A.P.P.; Formal analysis, B.B.W.; Investigation, B.B.W., A.W., S.U., and A.P.P.; Methodology, B.B.W.; Project administration, B.B.W., A.W. and A.P.P.; Resources, B.B.W., and A.W.; Software, S.U.; Supervision, B.B.W.; Validation, B.B.W., and S.U.; Visualization, A.W.; Writing—original draft, B.B.W.; Writing—review \& editing, B.B.W. All authors have read and agreed to the published version of the manuscript.

Funding: The research and APC was funded by Universitas Negeri Malang with grand number 5.3.232/UN32.14.1/LT/2021.

Institutional Review Board Statement: Not Applicable.

Informed Consent Statement: Not Applicable.

Data Availability Statement: Not Applicable, the study does not report any data.

Acknowledgments: The authors would like to acknowledge the support of the Faculty of Education and Institution of Research and Community Service of Universitas Negeri Malang Indonesia.

Conflicts of Interest: There is no potential conflict of interest in the research.

\section{References}

1. OECD. PISA 2018 Results, Combined Executive Summaries; OECD: Paris, France, 2019; Volume I-III.

2. Biçer, D. The Effect of Students' and Instructors' Learning Styles on Achievement of Foreign Language Preparatory School Students. Procedia-Soc. Behav. Sci. 2014, 141, 382-386. [CrossRef]

3. Vizeshfar, F.; Torabizadeh, C. The effect of teaching based on dominant learning style on nursing students' academic achievement. Nurse Educ. Pract. 2018, 28, 103-108. [CrossRef] [PubMed]

4. Gepila, E.C., Jr. Assessing teachers using Philippines standards for teachers. Univers. J. Educ. Res. 2020, 8, 739-746. [CrossRef]

5. Maisyaroh; Budi Wiyono, B.; Hardika; Valdez, A.V.; Mangorsi, S.B.; Canapi, S.P.T. The Implementation of Instructional Supervision in Indonesia and the Philippines, and Its Effect on the Variation of Teacher Learning Models and Materials. Cogent Educ. 2021, 8, 1962232. [CrossRef]

6. Wiyono, B.B.; Kusmintardjo; Sucipto. The Effective Supervision Techniques that Influence Teacher's Performance. Man India 2017, 97, 25-33.

7. Sahbaz, U. The Effectiveness of In-Service Training for School Counselors on The Inclusion of Student with Disabilities. Educ. Res. Rev. 2011, 6, 580-585.

8. Yavuz, M. Effectiveness of Supervisions Conducted by Primary Education Supervisors according to School Principals' Evaluations. J. Educ. Res. 2010, 103, 371-378. [CrossRef]

9. Glickman, D.; Gordon, S.P.; Gordon, J.M.R. Supervision and Instructional Leadership, a Developmental Approach; Pearson: Boston, MA, USA, 2007.

10. Glatthorn, A.A. Supervisory Leadership: Introduction to Instructional Supervision; Harper Collins Publishers: New York, NY, USA, 1998.

11. Burden, P.R.; Byrd, D.M. Methods for Effective Teaching: Meeting the Needs of All Students, 8th ed.; Pearson: Boston, MA, USA, 2019; Available online: https://www.pearson.com/us/higher-education/program/Burden-Methods-for-Effective-Teaching-Meetingthe-Needs-of-All-Students-with-Enhanced-Pearson-e-Text-Access-Card-Package-8th-Edition/PGM1768116.html (accessed on 3 November 2021).

12. Wiyono, B.B.; Triwiyanto, T. The Effective Development Techniques in Teacher Working Group Meeting to Improve Teacher Professionalism. Int. J. Eng. Technol. 2018, 7, 295-298.

13. Wiyono, B.B. The Effect of Self-Evaluation on The Principals' Transformational Leadership, Teachers' Work Motivation, Teamwork Effectiveness, and School Improvement. Int. J. Leadersh. Educ. 2018, 21, 705-725. [CrossRef]

14. Abdullah, A.G.B.; Sumapwa, A.M.; Alzaidiyeen, N.J. The Effect of Teacher Training Programme on Teachers' Productivity in Caprivi Region, Namibia. Int. J. Afr. Stud. 2009, 2, 14-21.

15. Reed, Y.; Davis, H.; Nyabanyaba, T. Investigating Teachers' "Take-up" of Reflective Practice from an In-Service Professional Development Teacher Education Programme in South Africa. Educ. Res. Rev. 2002, 6, 580-585. [CrossRef]

16. Shah, S.; Kiani, K.M.; Mahmood, Z.; Hussain, I. In-Service Training of Secondary Level Teachers: A Follow-up of Teachers' Performance in Comparative Perspective. J. Educ. Pract. 2011, 2, 40-50.

17. Wiyono, B.B.; Ulfatin, N.; Maisyaroh. Persepsi dan Sikap terhadap Program Sertifikasi, Keikutsertaan dalam Kegiatan Pengembangan, dan Profesionalisme Guru. Manaj. Pendidik. 2008, 22, 124-139.

18. Wiyono, B.B.; Kusmintardjo; Supriyanto, A. Grand Design Model Pembinaan Profesional Guru Berbasis Faktor-faktor Determinan Kinerja Guru. J. Ilmu Pendidik. 2014, 20, 165-175.

19. Wiyono, B.B.; Kusmintardjo; Imron, A. Effect of Humanistic Principles-based Active-Collaborative Supervision on Teachers' Competence. Acta Sci. Intellectus 2015, 1, 19-26. 
20. Wiyono, B.B.; Indreswari, H.; Prestiadi, D. The Use of Technology-Based Communication Media in The Teaching-Learning Interaction of Educational Study Programs in The Pandemic of Covid 19. In Proceedings of the 2021 IEEE 11th International Conference on Electronics Information and Emergency Communication, Beijing, China, 18-20 June 2021; pp. 1-5. [CrossRef]

21. Wiyono, B.B.; Ishaq, M.; Arafik, M. The Using of "Sipejar" to Support the Online Teaching-Learning Process in College Based on Gender, Year of Study, and Department. In Proceedings of the 2021 IEEE 4th International Conference on Electronic Information and Communication Technology (ICEICT), Xi'an, China, 18-20 August 2021; pp. 25-30. [CrossRef]

22. Wiyono, B.B.; Hadi, S.; Imron, A.; Indreswari, H. Use of Information Technology in Online Learning Process Applied by the Lecturers Based on the Education and Rank Level. In Proceedings of the 2021 10th International Conference on Educational and Information Technology (ICEIT), Chengdu, China, 18-20 January 2021; pp. 144-149. [CrossRef]

23. Wiyono, B.B.; Wedi, A.; Wahyuni, S.; Valdez, A.V. Use of Online Communication Media as A Student Learning Tool in College and Its Effect on the Achievement of Students. In Proceedings of the 2020 6th International Conference on Education and Technology (ICET), Malang, Indonesia, 17 October 2020; pp. 186-191. [CrossRef]

24. Wiyono, B.B.; Wedi, A.; Kusumaningrum, D.E.; Ulfa, S. Comparison of The Effectiveness of Using Online and Offline Communication Techniques to Build Human Relations with Students in Learning at Schools. In Proceedings of the 2021 9th International Conference on Information and Education Technology (ICIET), Okayama, Japan, 27-29 March 2021; pp. 115-120. [CrossRef]

25. Wiyono, B.B.; Kusumaningrum, D.E.; Triwiyanto, T.; Sumarsono, R.B.; Valdez, A.V.; Gunawan, I. The Comparative Analysis of Using Communication Technology and Direct Techniques in Building School Public Relation. In Proceedings of the 2019 5th International Conference on Education and Technology (ICET), Malang, Indonesia, 4-5 October 2019; pp. 81-86. [CrossRef]

26. Wiyono, B.B.; Indreswari, H.; Prastiawan, A. The Use of Communication Technology in Establishing Community Relationships Applied by School Administration Staff, in Relation to Their Education Level and Age. In Proceedings of the 2021 3rd International Conference on Computer Communication and the Internet (ICCCI), Nagoya, Japan, 25-27 June 2021; pp. 214-219. [CrossRef]

27. Maor, D.; Ensor, J.D.; Fraser, B.J. Doctoral Supervision in Virtual Spaces: A Review of Research of Web-Based Tools to Develop Collaborative Supervision. High. Educ. Res. Dev. 2016, 35, 172-188. [CrossRef]

28. Martin, P.; Kumar, S.; Lizarondo, L. Effective Use of Technology in Clinical Supervision. Internet Interv. 2017, 8, 35-39. [CrossRef]

29. Mathisen, P.; Bjørndal, C. Tablets as a digital tool in supervision of student teachers' practical training. Nord. J. Digit. Lit. 2016, 11, 227-247. [CrossRef]

30. Suparman, U. The Implementation of The ICT-Based Thesis Supervision at One of Postgraduate Programs in Indonesia. In Proceedings of the International Conference on Education and Language (ICEL), Bandar Lampung, Indonesia, 28-30 January 2013; p. 1.

31. Matyanga, C.M.J.; Dzingirai, B.; Monera-Penduka, T.G. Virtual Supervision of Pharmacy Undergraduate Research Projects during the COVID-19 Lockdown in Zimbabwe. Pharm. Educ. 2020, 20, 13-14. Available online: https:/ / pharmacyeducation.fip.org/ pharmacyeducation/article/view/1129 (accessed on 14 November 2021). [CrossRef]

32. Liu, K.; Miller, R.; Dickmann, E.; Monday, K. Virtual Supervision of Student Teachers as a Catalyst of Change for Educational Equity in Rural Areas. J. Form. Des. Learn. 2018, 2, 8-19. [CrossRef]

33. Gordon, R.M.; Wang, X.; Tune, J. Comparing Psychodynamic Teaching, Supervision, and Psychotherapy Over Videoconferencing Technology with Chinese Students. Psychodyn. Psychiatry 2015, 43, 585-599. [CrossRef] [PubMed]

34. Kopcha, T.J.; Alger, C. The Impact of Technology-Enhanced Student Teacher Supervision on Student Teacher Knowledge, Performance, and Self-Efficacy during the Field Experience. J. Educ. Comput. Res. 2011, 45, 49-73. [CrossRef]

35. Martens, D.M. Research and Evaluation in Education and Psychology; Sage Publications: Los Angeles, CA, USA, 2010.

36. Wiyono, B.B.; Indreswari, H.; Putra, A.P. The Utilization of "Google Meet" and "Zoom Meetings" to Support the Lecturing Process during the Pandemic of COVID-19. In Proceedings of the 2021 International Conference on Computing, Electronics Communications Engineering (iCCECE), Southend, UK, 16-17 August 2021; pp. 25-29. [CrossRef]

37. Wiyono, B.B.; Rasyad, A.; Maisyaroh. The Effect of Collaborative Supervision Approaches and Collegial Supervision Techniques on Teacher Intensity Using Performance-Based Learning. SAGE Open 2021, 11, 21582440211013780. [CrossRef]

38. Alfian; Wiyono, B.B.; Imron, A.; Arifin, I.; Humaisi, M.S. Development of the Supervision Model Based on Clinical Approach to Increase Managerial Competence of School Principal. Univers. J. Educ. Res. 2019, 7, 2472-2481. [CrossRef]

39. Andyani, H.; Setyosari, P.; Wiyono, B.B.; Djatmika, E.T. Does Technological Pedagogical Content Knowledge Impact on the Use of ICT In Pedagogy? Int. J. Emerg. Technol. Learn. (iJET) 2020, 15, 126-139. [CrossRef]

40. Samawi, A.; Arifin, I.; Wiyono, B.B.; Imron, A. Learning Supervision Strengthening Based on School Culture in Kindergarten. Int. J. Innov. 2019, 5, 11.

41. Wiyono, B.B. The Diagnostic Feedback Supervision Model Based on Information Technology as the New Strategy to Improve the Professional Competence of Academic Personnel in School Organization. 2021. Available online: https://ieeexplore.ieee.org/ document/9445370/ (accessed on 29 June 2021).

42. Mettiäinen, S.; Karjalainen, A.-L. ICT-Based Software as a Supervision Tool in Nursing Students' Clinical Training. Available online: https: / /www.doria.fi/handle/10024/74734 (accessed on 14 November 2021).

43. Rugaiyah; Sulartinah; Kustandi, C.; Rahmawatid, D.; Sujanto, B.; Karnatif, N.; Hartati, S. Clinical supervision using information technology to improve teacher quality. Int. J. Innov. Creat. Dan Chang. 2019, 10, 328-347.

44. Ansari, J.A.N.; Khan, N.A. Exploring the Role of Social Media in Collaborative Learning the New Domain of Learning. Smart Learn. Environ. 2020, 7, 9. [CrossRef] 
45. Martin, F.; Sun, T.; Turk, M.; Ritzhaupt, A. A Meta-Analysis on the Effects of Synchronous Online Learning on Cognitive and Affective Educational Outcomes. Int. Rev. Res. Open Distrib. Learn. 2021, 22, 205-242. [CrossRef]

46. Duncan, K.; Kenworthy, A.; McNamara, R. The Effect of Synchronous and Asynchronous Participation on Students' Performance in Online Accounting Courses. Account. Educ. 2012, 21, 1-19. [CrossRef]

47. Francescucci, A.; Rohani, L. Exclusively Synchronous Online (VIRI) Learning: The Impact on Student Performance and Engagement Outcomes. J. Mark. Educ. 2019, 41, 60-69. [CrossRef] 